\title{
Bench scale study of moving bed biofilm reactor application as pre-treatment of raw water for water treatment plant (Case study: Pesanggrahan River)
}

\author{
Rhefa Fauza Setiani ${ }^{1}$, Setyo Sarwanto Moersidik ${ }^{2, *}$, and Sandyanto Adityosulindro ${ }^{2}$ \\ ${ }^{1}$ Environmental Engineering Study Program, Faculty of Engineering, Universitas Indonesia, Depok, Indonesia \\ ${ }^{1}$ Department of Civil Engineering, Faculty of Engineering, Universitas Indonesia, Depok, Indonesia
}

\begin{abstract}
The quality of surface water in Jakarta is on a serious polluted status. In order to reduce the Water Treatment processing load, a pre-treatment process is needed to eliminate parameters such as organic matter, ammonia, color, taste, and odor. This treatment generally uses chemical and physical processes, such as chlorination and activated carbon that produce harmful byproducts. Moving Bed Biofilm Reactor (MBBR) is one of the solutions developed to reduce the nutrient and organic levels in raw water. This study aims to improve the quality of raw water, by reducing the concentration of $\mathrm{COD}, \mathrm{NH}_{3}-\mathrm{N}$, Phosphate, and TSS before entering the conventional process. Reactor performance is assessed based on contaminant removal efficiency with variation of residence time ( 1 hour, 1.5 hours, 2 hours). The reactor is operated by using Kaldness K1 as the medium and oxygen supply of $7 \mathrm{~L} / \mathrm{min}$. The optimum residence time is 1,5 hours with the ability to remove COD, $\mathrm{NH}_{3}-\mathrm{N}$, Phosphate, TSS 51.8\% $\pm 0.2 ; 54.3 \% \pm 0.28 ; 52.6 \% \pm 0.19$; and $77.7 \% \pm$ 0.14 respectively. Based on the optimum residence time, the kinetics of the ammonia removal rate in MBBR takes place at zero order, with a rate constant removal of $0.0056 \mathrm{~g} / \mathrm{m}^{2}$.day. The results showed that the higher concentration of ammonia, and organic contaminants treated, the higher the efficiency of MBBR. Apart from water quality improvement, pre-treatment process using MBBR can reduce coagulant dose from $50 \mathrm{mg} / \mathrm{L}$ to $9 \mathrm{mg} / \mathrm{L}$, to decrease raw water turbidity from $135 \mathrm{NTU}$ to 0.68 NTU before entering the coagulation-flocculation unit.
\end{abstract}

\section{Introduction}

According to water quality monitoring conducted by the Ministry of Environment and Forestry in 2015, it was known that $68 \%$ of river conditions in Indonesia were heavily polluted. In addition, based on the evaluation of the Jakarta river water quality conducted by Regional Environmental Agency in 2015, most of river in Jakarta were classified as heavily polluted. Pesanggrahan River is one of the surface water that still has the potential to be used as a source of clean water with quality improvements 1. Pesanggrahan River has not meet the requirements of the quality standard, based on the research of Regional Environmental Agency in 2015 the river included in the $\mathrm{C}$ category of water body, that is more suitable for use as fisheries and livestock water sources because they have pollutant levels that exceed drinking water parameters. The contamination is produced by domestic waste due to activities in the Pesanggrahan watershed area, which is dominated by agricultural and residential activities 2 .

The concentration of organic pollutants, and ammonia which exceeded the environmental threshold based on Government Regulation No. 82 of 2001 about raw water quality standards will make it difficult for water treatment plants to treat raw water 3. Since conventional water treatment plant (WTP) is generally not designed to remove organic parameters and ammonia, a pre-treatment process is required. So far, pre-chlorination has been used in most of WTP to remove organics and other contaminants in raw water (i.e. manganese, ammonia, and detergent). Nevertheless, the disadvantage of this process is the high cost and could produce carcinogenic byproducts such as trihalomethane and chlorophenol 3 .

To overcome the limitation of pre-chlorination, biological processes come with environmentally benign technologies which offer organics and ammonia removal without using chemicals and expensive operational costs. Moving Bed Biofilm Reactor (MBBR) is one of the solutions developed to reduce nutrient and organic levels in raw water and wastewater. This system has advantages over other biological pre-treatment process, such as Aerated Filter, Biological Contact Oxidation, and Membrane Bioreactor because the cost is cheap, does not require a lot of space and is quite efficient in removing pollutant 4. Research on the use of MBBR as a pretreatment unit for surface water treatment was carried out using a pilot-scale reactor, the system was raising a good

\footnotetext{
* Corresponding author: ssarwanto@eng.ui.ac.id
} 
interest because it could remove ammonia concentrations from the Yellow River sample water in China by $61.6 \%$ and COD 11, 53\% respectively 5. Another study also carried out for micro polluted water, using the Taihu River sample water in China. The study proved that the level of ammonia removal efficiency in the reactor reached $71.4 \pm$ $26.9 \%$ depending on the influence of temperature, organic load, and residence time 4.

Based on the description above, the purpose of this research is to prove that Pesanggrahan River is adequate to be considered as a source of clean water by using the MBBR system as the pre-treatment process in order to meet the class I water quality standard based on Government Regulations No. 82 of 2001. This research will be conducted on a laboratory scale, only focusing on variables $\mathrm{COD}, \mathrm{NH}_{3}-\mathrm{N}$, Phosphate, and TSS.

\section{Material and methods}

\subsection{Raw water characteristics}

Surface water was obtained from Pesanggrahan River in Cinere monitoring point. Characteristics of the raw water varies depend on environment condition. Influent characteristics throughout the research shown on table 1

Table 1. Characteristic of pesanggrahan river

\begin{tabular}{|c|c|}
\hline Parameter & $\begin{array}{c}\text { Concentration } \\
\text { Range }\end{array}$ \\
\hline $\mathrm{COD}$ & $24.3-106.2 \mathrm{mg} / \mathrm{L}$ \\
\hline $\mathrm{NH}_{3}-\mathrm{N}$ & $0.08-1.04 \mathrm{mg} / \mathrm{L}$ \\
\hline Phosphate & $0.12-0.74 \mathrm{mg} / \mathrm{L}$ \\
\hline $\mathrm{TSS}$ & $7-243.8 \mathrm{mg} / \mathrm{L}$ \\
\hline $\mathrm{DO}$ & $4.2-8.1 \mathrm{mg} / \mathrm{L}$ \\
\hline $\mathrm{pH}$ & $7.01-7.53$ \\
\hline
\end{tabular}

\subsection{MBBR configuration and operation}

The study was conducted using MBBR bench scale with a volume of $6 \mathrm{~L}(20 \times 15 \times 25 \mathrm{~cm})$ fabricated from plexiglass. The design of the reactor refers to the previous study 6 with the modification of the addition of the presedimentation zone (fig 1). Pre-sedimentation zone were made to reduce TSS concentrations before water was treated using media. The high TSS will reduce pollutant removal efficiency in biofilm systems, because it can clog media so that it inhibits biofilm growth 3 .

MBBR is filled with Kaldness $\mathrm{K} 1$ as the media with a density of $0.95 \mathrm{~g} / \mathrm{cm}^{3}$, which allows the media to move freely in the reactor. Media is made of polyethylene with a diameter of $10 \mathrm{~mm}$, height $7 \mathrm{~mm}$, and a specific surface area of $500 \mathrm{~m}^{2} / \mathrm{m}^{3}$. The filling of the media in the reactor is set at $40 \%$ volume, because the higher the percentage of the media, the removal efficiency will gradually decrease 6. Aeration is given through diffusor with a capacity of $7 \mathrm{~L} /$ minute. The water flowing process during the study was carried out continuously by downflow using a peristaltic pump with a flow rate of $100,66.7$, and 50 $\mathrm{mL} /$ minute. This research was conducted with three variations of detention time, which were $1,1.5$, and 2 hours.

\subsection{System start-up and experimental procedure}

Seeding process was carried out to grow bacteria in the media, by adding an inoculum in the form of activated sludge from the oxidation ditch unit of the Jababeka WWTP, with an MLVSS concentration of $6232.1 \mathrm{mg} / \mathrm{L}$. The system was operated by a batch method to support the formation of a biofilm layer, with a flow discharge of 100 $\mathrm{mL} / \mathrm{min}$. During the seeding process, a control over DO concentration above $2 \mathrm{mg} / \mathrm{L}$ was carried out 8 , pH of 6.5 -8.5 , and temperature of $25-35^{\circ} \mathrm{C} 11$ to support bacterial growth. The inoculation process was completed in 17 days, marked by the formation of a biofilm layer and the reach of steady state condition as indicated by the increasement in removal efficiency from $34-55 \%$ (days 10-17).

After the seeding process was completed, an acclimatization process was carried out as a process of microbial adaptation to the water of Pesanggrahan river. The process was carried out gradually for 10 days until $100 \%$ of the reactor volume was filled with Pesanggrahan river water. The acclimatization process was divided into four stages based on the composition of the reactor loading. Phasing was carried out with a loading percentage of $25 \%$, then it was continued with an increase of multiples of $25 \%$ every two or three days. Changes in load were carried out when the percentage of efficiency had increased because it was assumed that the bacteria in the reactor were familiar with the load given. The same treatment was given as it was given during the seeding process, to optimize the bacterial growth. The steady state condition was achieved when there is a steady increasement from $25 \%$ to $33 \%$. This indicates that microorganisms have succeeded in adjusting to the new load, which is indicated by the formation of thicker layers of biofilm due to multiple layers of growth, rapid cell division, and stable metabolism of microorganisms.

\subsection{Analytical methods}

The laboratory tests conducted to determine the concentration of COD, $\mathrm{NH}_{3}-\mathrm{N}$, Phosphate, and TSS from reactor's effluent, according to the National Standard of Indonesia (SNI 6989.72:2009). While both parameters, $\mathrm{DO}$ and $\mathrm{pH}$ were measured by $\mathrm{DO}$ and $\mathrm{pH}$ meter according to (SNI 06-6989.23: 2005). Each running of detention time is conducted within one week, with the process of monitoring water quality every day. One week's time was chosen to observe the tendency of the contaminant removal in a long period of time, besides that it was also adjusted to the operational time of the WTP that operated for a full week. 


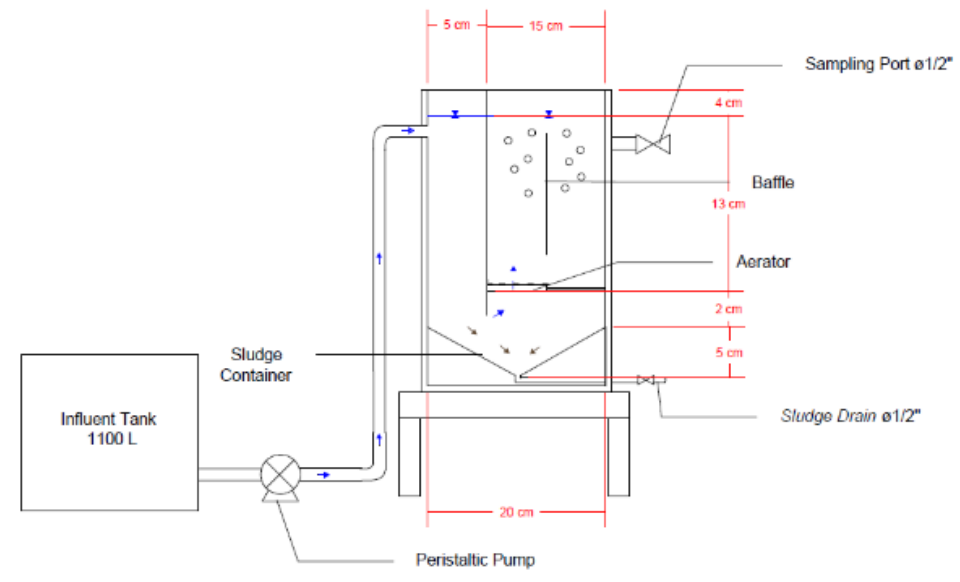

Fig. 1. Schematic of the Bench Scale Moving Bed Biofilm Reactor (MBBR).

\section{Result and discussion}

\subsection{COD Removal}

As shown in fig. 2, COD concentration varies depends on the operational condition. The study showed that by providing contaminants with high concentrations, the reactor could achieve higher removal efficiency. With an organic load of $2.6 \mathrm{~kg} / \mathrm{m}^{3}$ the reactor can reach an efficiency level of $88.3 \%$. Previous research explained that the higher the organic load was, the higher the COD removal efficiency became 11 . This was due to the consumption of carbon material by bacteria which caused an increase in removal efficiency as the organic load was increased. Organic substances that can be removed biologically are influenced by several variables, namely dissolved oxygen (DO), contact time, and the type and number of decomposing microorganisms 12 .

Removal efficiency at 1 hour was seen to decrease from 63.4 to $38.4 \%$ when there was an increase in DO concentrations of $7.7-8.1 \mathrm{mg} / \mathrm{L}$. Likewise with the level of efficiency at 2 hours, the level of efficiency has decreased from 47.7 to $44 \%$ when DO concentration has increased by 7.1-8 mg/L. Meanwhile, the efficiency level tended to be stable at 1.5 hours of residence with the highest removal of $81.7 \%$ and the DO concentration range of 7.45-7.7 mg L. This increase in concentration indicates a low level of oxygen consumption, due to death by substrate-decomposing bacteria 10 .

Based on this research, $\mathrm{pH}$ and efficiency level has a proportional relationship, which is characterized by an increase in $\mathrm{pH}$ and efficiency simultaneously. At 1 hour residence time, optimum efficiency was achieved at $63.4 \%$ with a $\mathrm{pH}$ of 8.3 . While at 1.5 hours HRT was achieved when the efficiency was $81.2 \%$ with a $\mathrm{pH}$ of 8.33. As well as 2-hour HRT with an efficiency level of $47.7 \%$ and $\mathrm{pH} 8.29$. Based on a previous research, $\mathrm{pH}$ conditions had a significant effect on COD removal. Therefore, it was necessary to maintain $\mathrm{pH}$ because heterotrophic bacteria grew optimally in the $\mathrm{pH}$ range 7813.
The experiment showed that the effluent from MBBR has not met Class I Quality standard based on Government Regulation No.82 of 2001. The average concentration of the effluent is $49.41 \mathrm{mg} / \mathrm{L}$ which only meet the Class III Quality standard, with a maximum concentration limit of $50 \mathrm{mg} / \mathrm{L}$.

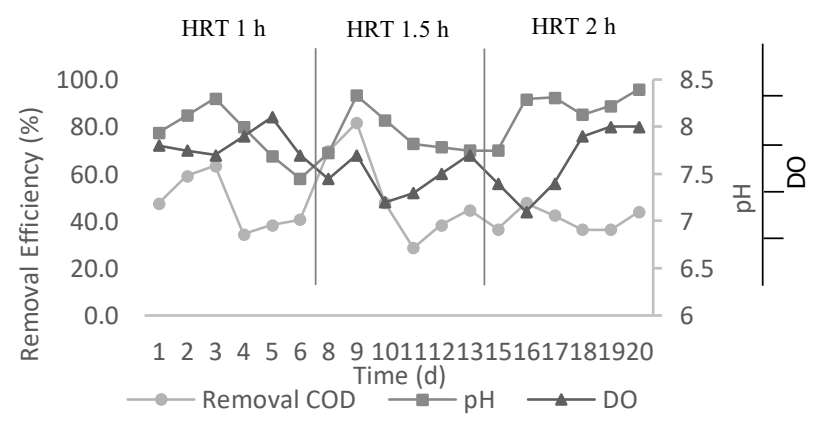

Fig. 2. COD removal efficiency, DO, and $\mathrm{pH}$ during operational period

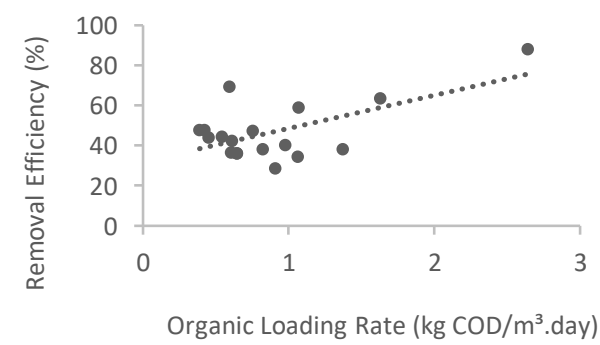

Fig. 3. COD removal rates versus COD loading rates in the MBBR system

\section{2. $\mathrm{NH}_{3}-\mathrm{N}$ removal}

The nitrification rate in MBBR is influenced by three factors, which are organic load, ammonia load, and oxygen concentration. In order for the nitrification process to take place, a load of more than $4 \mathrm{~g} / \mathrm{m}^{2}$.day and a concentration of oxygen above $6 \mathrm{mg} / \mathrm{L}$ can take place 11 . In addition, the research also showed that with a load range of $0.1-4.43 \mathrm{~g}-\mathrm{N} / \mathrm{m}^{2} \mathrm{~d}$ the highest removal was achieved at $93 \%$.

\footnotetext{
* Corresponding author: ssarwanto@eng.ui.ac.id
} 


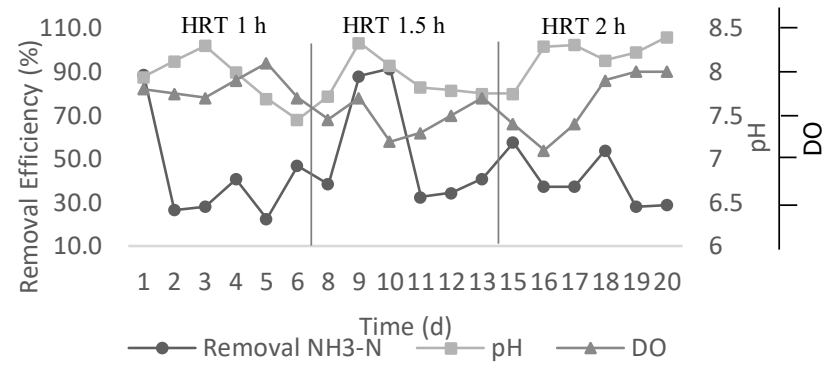

Fig. 4. $\mathrm{NH}_{3}-\mathrm{N}$ removal efficiency, $\mathrm{DO}$, and $\mathrm{pH}$ during operational period

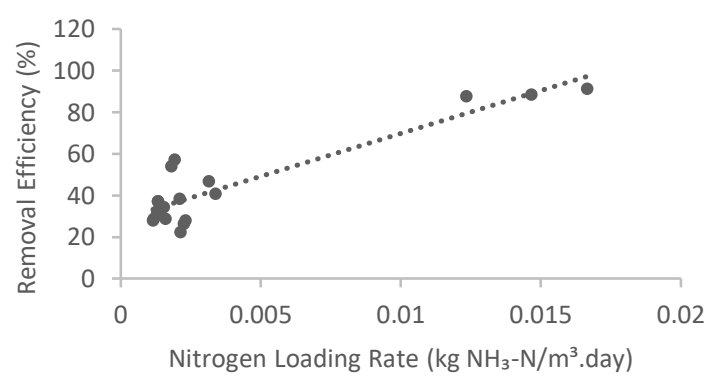

Fig. 5. $\mathrm{NH}_{3}-\mathrm{N}$ removal rates versus ammonia loading rates in the MBBR system

In this study, the $\mathrm{pH}$ range was kept at 7 to 8.5 because the nitrification rate decreased significantly when the $\mathrm{pH}$ was below 6.8. Specifically, the optimum $\mathrm{pH}$ range for Nitrosomonas and Nitrobacter bacteria is 7.9-8.8 and 7.2-7.6 respectively. On the first three days, it was seen that the $\mathrm{pH}$ decreased, this was because at the initial stage of the nitrification process consumed alkalinity, which caused a decrease in $\mathrm{pH}$. The nitrification process involves the release of $\mathrm{H}^{+}$ions, the higher the nitrification rate, the more acidic the $\mathrm{pH}$ of the solution. Therefor the condition of the $\mathrm{pH}$ of the reactor is very dependent on the buffer capacity of the water, to maintain $\mathrm{pH}$ conditions in the nitrification process.

For $\mathrm{NH}_{3}-\mathrm{N}$ removal, bacteria were very dependent on DO concentration. This was because DO was a cosubstrate in the nitrification process, because it was able to carry out the nitrification process, an oxygen concentration of more than $1 \mathrm{mg} / \mathrm{L}$ was needed 10 . If the oxygen concentration was lower, it would be the limiting factor and the nitrification could run slower.

The effluent from MBBR has already met the Class I Quality standard based on Government Regulation No.82 of 2001. The average concentration of the effluent was $0.07 \mathrm{mg} / \mathrm{L}$ which is still far compared to the Class I Quality Standard, which is $0.5 \mathrm{mg} / \mathrm{L}$. That means the treated water is suitable to be used as a source of drinking water.

\subsection{Phosphate removal}

The experimental results showed phosphate loading rate about $0.00192-0.01184 \mathrm{~kg} \mathrm{P} / \mathrm{m}^{3}$.day could achieve phosphate removal efficiency up to $87.23 \%$. Previous research has also explained this condition, the highest phosphate removal rate is reached when the load was given more than $0.2 \mathrm{~kg} \mathrm{P} / \mathrm{m}^{3}$.day, with efficiency removal of $98 \% 11$. Apart from the loading rate given, efficiency removal also dependent on the operational conditions of the reactor. DO concentration needs to be given continuously to ensure that there is oxygen in the biofilm layer. The process of phosphate removal in water is affected by bacterial polyphosphate accumulating organisms (PAO) under aerobic conditions 14. The microorganisms consume phosphate, so the phosphate content in the water decreases gradually. The process of phosphate removal is inhibited by the accumulation of nitrite, therefore it is necessary to have an adequate aerobic phase to achieve the perfect nitrification process. Apart from DO, PAO bacteria also need to maintain $\mathrm{pH}$ conditions during the operational process. In order to gain an optimal removal efficiency, $\mathrm{pH}$ was maintained by range of 7-8 for optimum growth of PAO bacteria. Previous research showed that PAO bacterial population has decreased when there is a decrease in $\mathrm{pH}$ from 8 to 6.5 15. The effluent from MBBR has already met the Class I Quality standard based on Government Regulation No.82 of 2001. The system managed to decrease the phosphate concentration until it reached $0.106 \mathrm{mg} / \mathrm{L}$, while the threshold has the limit concentration of $0.2 \mathrm{mg} / \mathrm{L}$.

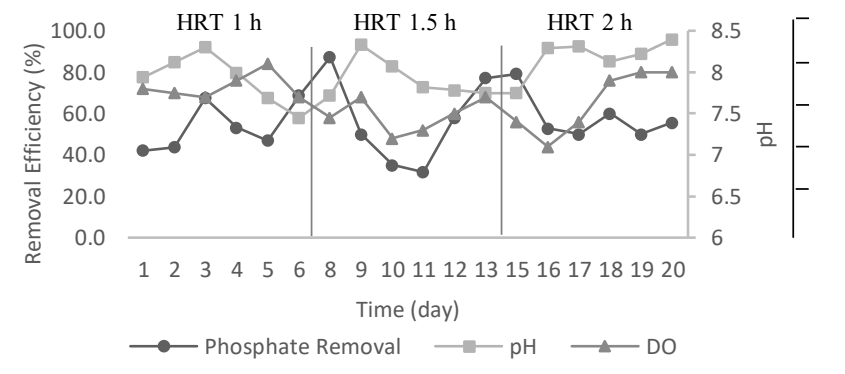

Fig. 6. Phosphate removal efficiency, DO, and $\mathrm{pH}$ during operational period

\subsection{TSS Removal}

Based on the performance of each residence time, the level of TSS removal efficiency from 1 hour, 1.5 hours, and 2 was $50.6 \%-80 \% ; 57.5 \%-88.9 \%$; and $53.6-89.2 \%$ respectively. The high removal rate was obtained from the flow model and addition of the pre-sedimentation zone. The flowing process causes suspended solids in the water to settle in the pre-sedimentation zone, due to a decrease in the water velocity. The research showed that the optimum performance of TSS parameter removal were obtained at 2 hours residence time. The longer the contact time, the higher the level of TSS removal. Because it has more time to settle at the bottom of the reactor 17. MBBR as a pre-treatment process managed to decrease the concentration of TSS until it reached $12.8 \mathrm{mg} / \mathrm{L}$, while the threshold has the limit concentration of $50 \mathrm{mg} / \mathrm{L}$. 


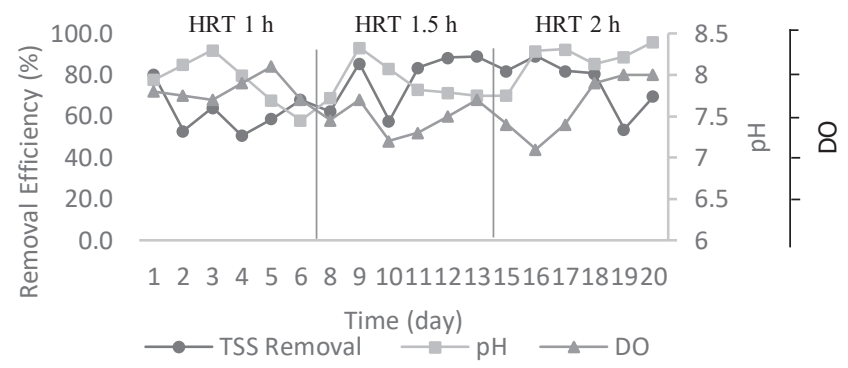

Fig. 8. TSS removal efficiency, DO, and $\mathrm{pH}$ during operational period

\subsection{Optimum HRT for MBBR as pre-treatment process}
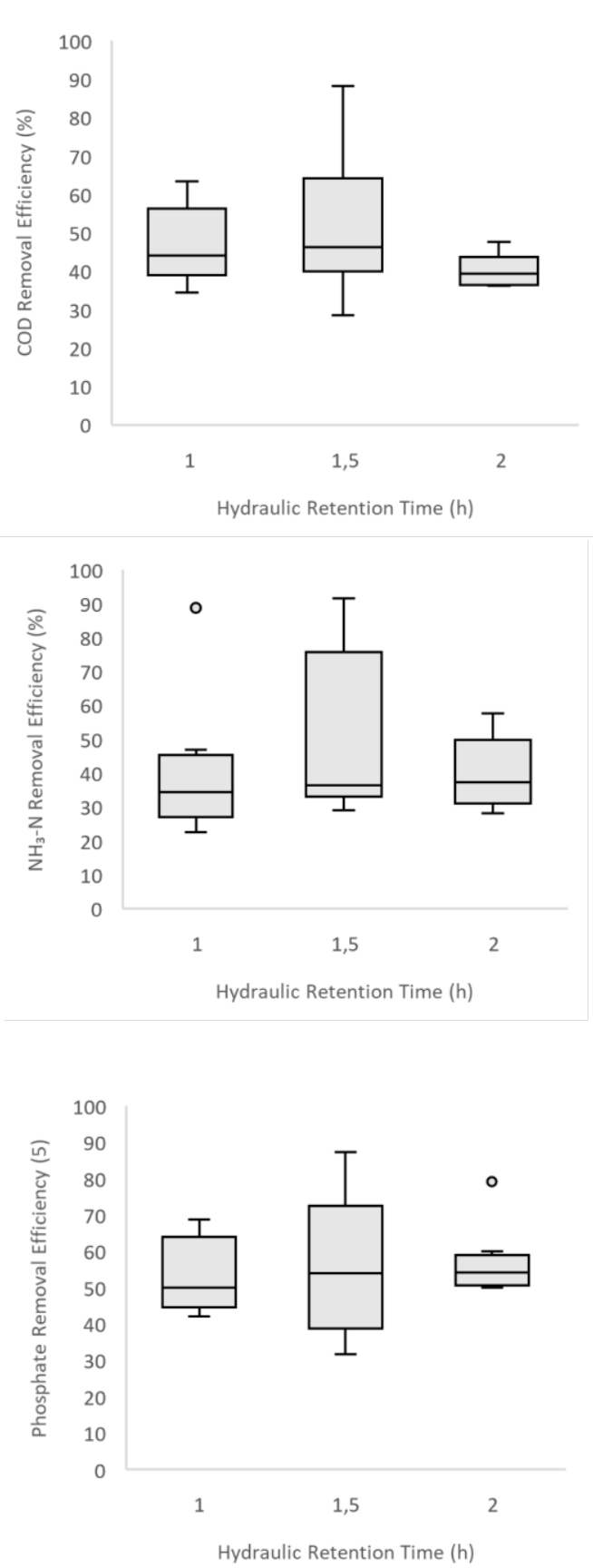

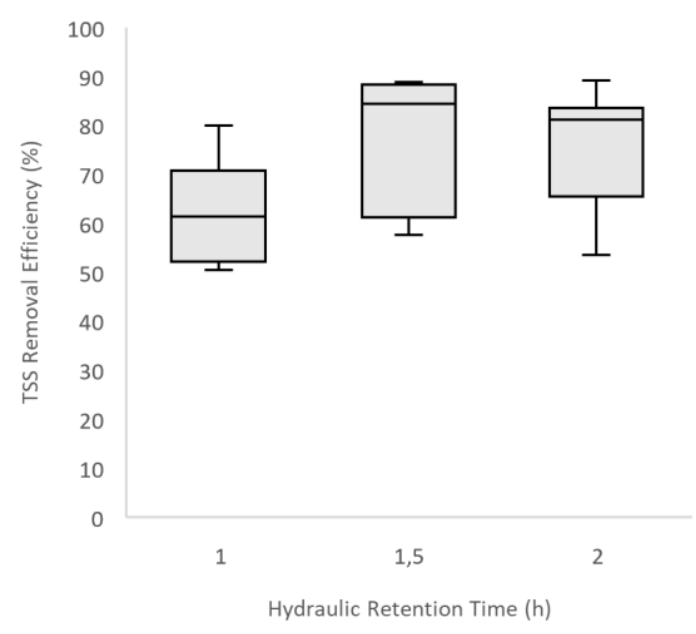

Fig. 9. Box Plot removal efficiency of a) $\mathrm{COD}$, b) $\mathrm{NH}_{3}-\mathrm{N}$, c) Phosphate, and d) TSS on MBBR

Determination of optimal detention time referred to the removal efficiency of COD, $\mathrm{NH}_{3}-\mathrm{N}$, Phosphate, and TSS with variations in HRT. In order to identify the data distribution and minimum allowance, boxplots were used to adjust the effluent to quality standard. When viewed from ANOVA test, there is no significant differences occurred in each parameter removals $(\mathrm{P}>0.05)$, so the decision-making continued by using box plots. Box plots also used to see the minimum removal, whether it has met with the environmental threshold or not.

When viewed from the median, there was no significant difference between $\mathrm{COD}, \mathrm{NH}_{3}-\mathrm{N}$, and Phosphate. If the median value had similarities, the comparison would be seen from Q3 and whisker length at the top of the box 18. For the COD removal efficiency, 1.5 hours of HRT had a Q3 value and the maximum value was higher when compared to 2 hours of HRT. This indicates that the removal rate of 1.5 hours of HRT could reach a high value of $81.7 \%$. In addition, the average HRT effluent of 1.5 hours was closer to the target of class I Government Regulations No. 82 of 2001. At $\mathrm{NH}_{3}-\mathrm{N}$ removal rate, there was also a median similarity, so that the comparison seen from Q3 and whisker length at the top of the box was determined to be 1.5 hours as optimal detention time. At $1.5 \mathrm{~h} \mathrm{HRT}$, whiskers had a considerable range with a bottom line at $32.97 \%$ removal with effluent concentration $0.054 \mathrm{mg} / \mathrm{L}$ which is beyond the standard quality limit $(0.5 \mathrm{mg} / \mathrm{L})$. As for phosphate removal efficiency, the optimal detention time reached by $1 \mathrm{~h}$ because of the lower whiskers had a higher removal rates than the others which were $44.53 \%$ with the effluent concentration of $0.09 \mathrm{mg} / \mathrm{L}$, exceeding the quality standard. Meanwhile for the TSS optimal detention time, 2h HRT was chosen because of the highest median and $\mathrm{Q}_{1}$ than the others $(84.52 \%$ and $67.65 \%$ respectively). Based on the results of these statistics analysis, $\mathrm{COD}, \mathrm{NH}_{3}-\mathrm{N}$, Phosphate, and TSS effluents has already meet the quality standards. Therefore, HRT $1.5 \mathrm{~h}$ was chosen as the optimum detention time to removes pollutants from the Pesanggrahan River. 


\subsection{Nitrification kinetics}

After obtaining the optimum detention time of MBBR, a batch experiment was conducted to determine the $\mathrm{NH}_{3}-\mathrm{N}$ removal kinetics on MBBR. During this experiment, the same treatment was given to the system as it was given during continuous trials with a detention time of 1.5 hours. At the start of the batch trial, tests were carried out on the concentrations of $\mathrm{NH}_{3}-\mathrm{N}$ to determine the initial concentration of ammonia nitrogen in water sample used. The observation was carried out for 4 hours with initial $\mathrm{NH}_{3}-\mathrm{N}$ concentration level of $0.44 \mathrm{mg} / \mathrm{L}$.

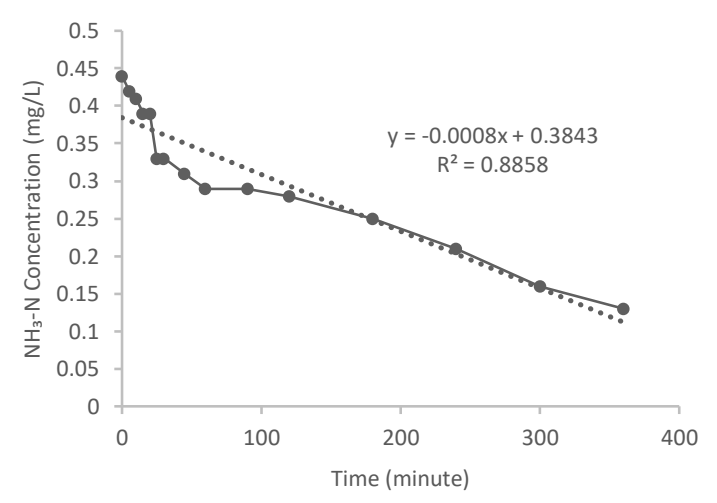

Fig. 10. Nitrification kinetics on MBBR system

Based on figure 11, it is known that the kinetics of ammonia removal rate in MBBR takes place at zero order, with a removal rate constant of $0.0056 \mathrm{~g} / \mathrm{m}^{2}$.day. Zeroorder removal rate constant would increase significantly as the load was being processed, hence the zero-order removal rate constant reflected the maximum reaction rate limited by bacteria metabolism 19. Previous research had also explained this condition, the nitrification rate showed a strong relation to the ammonium loading rate in aerobic conditions 10 .

\subsection{Coagulant demand}

This study also analyzed the coagulant dosage to treat the Pesanggrahan Surface Water. MBBR as pre-treatment process is expected to reduce the processing load from the Coagulation and Flocculation unit in WTP, which is characterized by increasement in coagulant demand. The coagulant used in this study is liquid PAC which content $10 \%$ alumina, with a dose range of $30-70 \mathrm{mg} / \mathrm{L}$. The dosage refers to the coagulant demand for raw water processing with turbidity 60-90 NTU, while the Pesanggrahan River water only has turbidity concentration of 135 NTU.

Based on the jar test, it was found that before using MBBR technology, WTP needed a coagulant dosage of $50 \mathrm{mg} / \mathrm{L}$ to reduce the raw water turbidity from 135 to $0.28 \mathrm{NTU}$, and COD concentration from 33 to $19 \mathrm{mg} / \mathrm{L}$. After using MBBR as pre-treatment, the coagulant needed to achieve the same effluent condition is $9 \mathrm{mg} / \mathrm{L}$. The dose was able to reduce COD concentration from $40.5 \mathrm{mg} / \mathrm{L}$ to $22 \mathrm{mg} / \mathrm{L}$, and turbidity from $7.69 \mathrm{NTU}$ to $0.68 \mathrm{NTU}$. Based on these tests, it is known that MBBR technology can reduce the coagulant usage by $84 \%$ in WTP, hence minimizing the costs incurred for coagulant materials.

\section{Conclusion}

The study shows that Pesanggaran River could be used as a source of clean water by using MBBR as the pretreatment process. The raw water treated has improved in quality, marked by decrease in concentration in each parameter. The determination of the performance of MBBR is seen from the parameter removal efficiency with a variety of residence times, which were 1 hour, 1.5 hours, and 2 hours. Based on statistical analysis, the optimum detention time obtained to treat Pesanggrahan river water is 1.5 hours. With this detention time, MBBR was able to reach the level of $\mathrm{COD}, \mathrm{NH}_{3}-\mathrm{N}$, Phosphate, and TSS $51.8 \% \pm 0.2 ; 54.3 \% \pm 0.28 ; 52.6 \% \pm 0.19 ;$ and $77.7 \% \pm$ 0.14 respectively. During the research, effluent concentration had met the class I quality standards based on PP 82 of 2001 for the categories of Ammonia, Phosphate, and TSS. For COD, concentration only meets class III quality standards, so it is necessary to carry out an advanced treatment process to reduce the COD concentration. During the research process, DO concentrations are always above $4 \mathrm{mg} / \mathrm{L}$. This concentration is sufficient to provide conditions where there is a perfect nitrification process, so that ammonia nitrogen contained in river water will be converted into nitrite and nitrate. $\mathrm{pH}$ range was also kept at 6.5 to 8.5 in order to optimize the bacterial growth, and also prevent competition between autotrophic and heterotrophic bacteria. Apart from water quality improvement, pretreatment process using MBBR can reduce coagulant dose from $50 \mathrm{mg} / \mathrm{L}$ to $9 \mathrm{mg} / \mathrm{L}$, to decrease raw water turbidity from $135 \mathrm{NTU}$ to $0.68 \mathrm{NTU}$ and COD from $33 \mathrm{mg} / \mathrm{L}$ to $22 \mathrm{mg} / \mathrm{L}$ before entering the coagulation-flocculation unit.

This study was supported by Universitas Indonesia under the study of PITTA 2018 (International Indexed Publication for Universitas Indonesia Student Final Project) funding scheme, with contract number 2529/UN2.R3.1/HKP.05.00/2018

\section{References}

1. R Yanidar., D.M Hartono., S Moersidik. Water quality assessment for self-sufficient water resources for DKI Jakarta. In IOP Conference Series: Earth and Environmental Science (Vol. 106, No. 1, p. 012056). IOP Publishing. (2018)

2. S. M Fathana.The Effect of Land Use Changes in Ciliwung and Pesanggrahan Watershed (Bahasa). (Doctoral dissertation, Bogor Agricultural University (IPB)). (2017)

3. R. Nugroho \& N. I Said. Improvement of raw water quality at Drinking Water Company with Biofiltration Process (Bahasa). Journal of Environmental Technology, 12(2): 121-129. (2011)

4. Z, Shuangfu., Y. Wang, He, W., Wu, M., M, Xing. J, Yang \& D, Yin. Responses of biofilm characteristics to variations in temperature and $\mathrm{NH}$ 
4+-N loading in a moving-bed biofilm reactor treating micro-polluted raw water. Bioresource technology. 131, 365-373. (2013)

5. S. Xiangyang. Enhanced treatment of polluted surface water from Yellow river (China) with biooxidation as pretreatment: Pilot scale studies. Desalination and Water Treatment, 9(1-3): 59-65. (2009)

6. Z, Shuangfu., Y. Wang, He, W., Wu, M. M, Xing. J, Yang. D, Yin. \& M, Pan. Impacts of temperature and nitrifying community on nitrification kinetics in a moving-bed biofilm reactor treating polluted raw water. Chemical Engineering Journal, 236, 242-250. (2014)

7. J.S., Alvarez, M. Tang, R. W. C. Horvath, \& J. F. Stahl, Evaluation of moving bed biofilm reactor technology for enhancing nitrogen removal in a stabilization pond treatment plant. Proceedings of the Water Environment Federation, 2005(14), 20852102. (2005)

8. X. J. Wang, S. Q. Xia, L. Chen, J. F. Zhao, N. J. Renault \&, J. M. Chovelon, 2006. Nutrients removal from municipal wastewater by chemical precipitation in a moving bed biofilm reactor. Process Biochemistry, 41(4): 824-828.

9. C, Tchobanoglous. Wastewater engineering: Collection and pumping of wastewater. In Wastewater engineering: collection and pumping of wastewater. McGraw-Hill Book. (1981)

10. A. Zafarzadeh., B. Bina, M. Nikaeen, H. M. Attar, \& M. H Nejad. Performance of moving bed biofilm reactors for biological nitrogen compounds removal from wastewater by partial nitrificationdenitrification process. Iranian Journal of Environmental Health Science \& Engineering, 7(4): 353. (2010)

11. H. Ødegaard. The new moving bed biofilm reactor. Water Science and Technology. (1999)

12. G, Bitton. Wastewater microbiology. John Wiley \& Sons. (2005)

13. V. Hoang, MBBR Ammonia Removal: An Investigation of Nitrification Kinetics, Biofilm and Biomass Response, and Bacterial Population Shifts During Long-Term Cold Temperature Exposure. University of Ottawa (Canada). (2013)

14. M. Christensson. Enhanced Biological Phosphorus Removal-Carbon sources, nitrate as electron acceptor, and characterisation of the sludge community. (1997)

15. T. Fukushima, M. Onuki, H. Satoh, \& T. Mino, Effect of $p H$ reduction on polyphosphate-and glycogen-accumulating organisms in enhanced biological phosphorus removal processes. Water Science and Technology, 62(6), 1432-1439. (2010).

16. Nurhidayanti. Improvement of raw water quality using fixed bed reactor technology with pumice media (Bahasa). (Undergraduate thesis, Bogor Agricultural University (IPB)). (2011)
17. S. Y. A. Bodkhe, Modified anaerobic baffled reactor for municipal wastewater treatment. Journal of Environmental Management, 90(8), 2488-2493. (2009)

18. V. Ferreira, J. E., Miranda, R. M., Figueiredo, A. F., Barbosa, J. P., \& Brasil, E. M. Box-and-Whisker Plots Applied to Food Chemistry. Journal of Chemical Education, 93(12): 2026-2032. (2016)

19. V. Ahnen, M., Pedersen, L. F., Pedersen, P. B., \& Dalsgaard, J. Degradation of urea, ammonia and nitrite in moving bed biofilters operated at different feed loadings. Aquacultural engineering, 69: 50-59. (2015) 